\title{
The Chinese Road of the Cooperative Education Mechanism of Family, School and Society
}

\author{
Changqing Pang \\ Department of Basic Courses, Shandong University of Science and Technology, Jinan, Shandong, China.
}

\begin{abstract}
How to cite this paper: Changqing Pang. (2021). The Chinese Road of the Cooperative Education Mechanism of Family, School and Society. The Educational Review, USA, 5(8), 270-274.

DOI: 10.26855/er.2021.08.003

Received: July 12, 2021

Accepted: August 8, 2021

Published: August 20, 2021

Corresponding author: Changqing Pang, Department of Basic Courses, Shandong University of Science and Technology, Jinan, Shandong, China.

Email: 13853184438@163.com
\end{abstract}

\begin{abstract}
Education is not only related to knowledge imparting and learning, but also related to the inheritance and future of national culture and morality. The full play of its social attribute has become an important symbol of future education. However, there is still a long way to go for the effect of the cooperative education mechanism of family, school and society, such as the lack of understanding of the essence of the cooperative education mechanism of family, school and society, serious formalism, unclear obligations and responsibilities of all parties, low participation, lack of professionalism and so on. This paper studies the national attribute of youth education, aiming to reverse the traditional beliefs on family, school, and community education, establish the principles of maximizing the interests of young people, and national guardianship of youth education. Further on, the division of educational responsibilities and obligations among family, school and community are talked about, including public interest of family education, effectiveness of school education, and emotional support and identity cognition of social education, which should be recognized as the Chinese localization solutions of school, family, and social cooperative education mechanism.
\end{abstract}

Keywords

Youth Education, Family, School, Community, Cooperative Education

\section{Introduction}

The young generation describes the future of the world, and the youth education describes the quality of the young generation. With the economic and social progress improving, China has determined to energize the full play of raising the level of youth education unprecedentedly, which is why the proposition of "we should improve the school, family, social cooperative education mechanism" is clearly stated in the Fourteenth Five-year Plan for National Economic and Social Development of the People's Republic of China and the Outline of Long-term Goals for 2035 (The Chinese Government, 2021). Meanwhile, the Family Education Law of the People's Republic of China is being drafted, which emphasizes the principle of "close integration and coordination of family education, school education and social education" (The NPC, 2021). More and more people have come to the consensus that family, school and society should cooperate in educating young people. In this scenario, what kind of implementation strategy is adopted becomes the key factor to determine its effectiveness.

\section{The status quo of cooperative education between family, school and society}

\subsection{Parents and society are not fully involved in the cooperative process}

First of all, the existing forms of cooperative education of family, school and society are mainly lectures and parent-child activities involved, and the organizers aim at organizing itself, but not achieving normalized patterns of effec- 
tive education cooperation. Parents just care about how to benefit their own children selfishly, ignoring the interests of the collective group. Utilitarianism has always been their motive for them to have access to the mechanism, since what most of them want is to try every means to let their children get high school grades to go into a leading school. In this way, individual part in the mechanism just plays its own role, far away from cooperation (Chaohui Chu, 2021).

\subsection{The existing social education resources are not targeted}

Social education resources are provided in a narrow-minded way, since communities only consider education places, materials, and children's activities to be all about education cooperation. Factually, these are only the small part of the story. Even worse, some books and materials displayed in children's activity places have no traces of reading, and the content is inconsistent with family education and children's needs, which shows that the pertinence and effectiveness of education is not high. Basically, what is ignored is that education is not only something about material, but only something about spirit and emotion.

\subsection{The professionalism of family education and social education needs to be improved}

Presently, a great gap is very obvious in the professional level of the three parties in the family, school, and community collaborative education, such as lack of understanding of the nature of the cooperative education mechanism between family, school and society, serious formalism, unclear obligations and responsibilities of all parties, etc. What is bothering is that the three parties are not provided with effective professionalism of being clear about what their roles are, what they should do, and in what effective way they can play their own parts. In this way, education on cooperation-education professionalism has to be the immediate task to ensure the initiative effective.

\section{What should the state do}

Traditionally, education was seen as a way to make fortune and to be politically successful, which is why moral standard is ignored in some senses, and originality and creativity are not taken seriously. So, the most important core thing we have to be clear about is the question of what should be educated to our young people, and what values we should educate our children. It is our duty to ensure that all schools, public or private, inculcate habits of critical reasoning and reflection, a way of thinking that implies a tolerance of and respect for other points of views. In pursuit of this lofty goal, the state must see that all children are provided with an education that is, in the fullest sense, public-a schooling that gives children the tools they will need to think for themselves, a schooling that exposes children to other points of view and to other sources of meaning and value than those they bring from home. This effort may well divide child from parent, not because socialist educators want to indoctrinate children, but because learning to think for oneself is what children do. It is one facet of the overall movement toward the individuation and autonomy that is "growing up" and is, perhaps, the most natural and vital part of healthy maturation (Jeffrey Shulman, 2020).

\section{What should parents do}

Parents are trustees of national education. Parents' educational power is bound by parents' educational obligation, while parents' educational obligation is bound by state responsibility. The obligation of the state to educate children is higher than the right of any parent. Under the national legal system, the right of parents to guiding the upbringing of their children is a matter of obligation rather than right. The main obligation of parents is to provide appropriate education for their children, but they have no right to force their children to accept education beyond the national setting. The scope of parents' power to guide their children's education is always limited, which is determined by their children's best interests and the legitimate needs of the country. The state has an independent interest in children's education. The power of parents to educate their children is limited by the assumption that children are not born for the interests of their parents, but for the country. This power is not for the benefit of parents, but for the benefit of children.

We should establish a system of compulsory education for parents and impose the national responsibility of family education on young parents. Teenagers are the future of the country, and family education is an important part of the country's future. The concept of self-interest in family education needs to be fundamentally reversed, and the national responsibility of family education needs to be clarified. Parental education should be identified as a core preventive service. Through parent education, we can provide parents with knowledge, resources and support to cultivate their parenting skills and improve the well-being of children and families. At the same time, it can also help parents learn tools and strategies, provide a positive and cultured family environment, and make their children grow up healthily physically, emotionally and cognitively, which is of great benefit to parents, children and families.

The benefits of parent education are as follows: (a) having a deeper understanding of adolescent development and ef- 
fective ways of communication, and improving positive parenting methods; (b) strengthening social ties through the exchange of views, the provision and access of support and sharing resources between parents; (c) improving the quality of parent-child interaction because parents can learn how to contact their children; (d) improving parenting skills and cultivating parents' educational knowledge to help to reduce parents' depression, anxiety, anger, guilt and pressure, thus improving parents' mental health and well-being; (e) reducing the risk of corporal punishment and child abuse, as parents learn alternatives to corporal punishment and new ways to think about appropriate family roles and expectations of children; (f) making parents more self-confident and powerful with the improvement of care skills and parents' roles.

Besides, role efficacy of parents is also important. Parenting is more challenging than ever. The effectiveness of parents' role refers to the effectiveness of parents' behavior in the interaction with their children and the whole process of socialization. Children's parents are responsible for children's physical, safety, cognitive and emotional development, micro-management of their children's integration into society, cultivating their socially acceptable behavior, and effective integrating children's cognitive and psychological development with society. Parental efficacy refers to the behavior that parents show in the process of interaction with their children, which plays an important role in children's cognition, psychosocial development and adaptation, including the happiness and satisfaction that parents feel when they perform their daily duties related to taking care of their children (Demetriou Loukia1 \& Kalouri Ourania, 2019).

\section{What should communities do}

With the development of communication technology, teenagers are vulnerable to the influence of various trends of thought brought by the proliferation of social media. Many uncensored or unfiltered content and services cause mental confusion to teenagers. The future of a country depends on the field of education. If the foundation of education is properly set when people are very young, it will be carried forward later. Otherwise, it will be absurd. In today's environment surrounded by social media, it is very important to provide proper guidance and understanding for teenagers. In view of this, to carry out Internet literacy or digital literacy courses in schools is an important content to help teenagers adapt to and analyze the social environment.

The above is just part of the story to reform the status quo of the community education, and much more has to be done immediately. The vigorous development of community voluntary activities is a link between schools, families and society, and an important way to educate people together. Ideally, besides the school learning environment of academic competition, communities need to create social emotional learning environment, self-confidence participation learning environment, and motivation-oriented learning environment. Actions have to be taken quickly to reduce the opportunities for young people to be isolated, especially in their families, and develop the development characteristics of youth communities by developing mutual friendship between their families and communities. One misunderstanding has to be dropped that communities are just places for students to learn knowledge out of school, but environment for students to be emotionally, spiritually, and professionally improved to feel real things of the social reality and to be energized to get ready for devotion to the establishment of the future of communities.

\section{What should schools do}

Rationally speaking, traditional school education ignores the subjectivity, diversity and dispersion of educational knowledge, but believes in the hierarchical system of rational ability, which is clearly manifested in large-scale knowledge input, and attempts to overcome various cognitive risks with the help of rational individual's "free balance reason”, but eventually leads to the isolation, absolutization and personification of knowledge. The government's overall regulation of education, the closed exploration of fragmentation, the reform goal divorced from the life situation, the scientific management based on cumbersome rules, the forced transformation of teachers' concept, and the practice concept of unilateralism all embody the compulsion of school reform.

With the integrated, intelligent, ubiquitous and interconnected educational reform process of "destandardization" and "debureaucracy" of future schools in the era of artificial intelligence, the educational reform is bound to touch the fundamental changes of modern school system, in order to explore the educational system innovation to match the era of intelligence. The first issue of modern school reform is related to how to realize the autonomy of schools, so as to break the rigid system of public education formed in the industrial age and realize the modern transcendence of school governance system.

In the USA, The Progressive Education Association (PEA) carried out a school survey and educational system reform in secondary education from 1933 to 1940. The "eight-year study" put forward many initiatives to challenge the "modern school system", such as supporting students to think independently, giving teachers more freedom of education, promoting more democratic classroom and supporting schools to carry out social change. The 30 schools participating in the experiment have special selection system guarantee in college enrollment, which stimulates the innovative prac- 
tice of education and teaching reform in these schools. Just as the current dilemma of the reform and innovation of basic education in China, especially the dilemma of the diversified innovation and development of ordinary high schools, behind it is the shackles of the enrollment and examination system of higher education, which makes the innovation and development of basic education schools extremely difficult, thus making "college entrance examination factories" (schools are just like factories whose sole purpose is to produce unified students for colleges) prevail. Only by unlocking the college enrollment and examination system, the innovative development of compulsory education schools and the diversified development, characteristic development and personality development of ordinary high schools can have the conditions and foundation of "system innovation".

The fundamental reform of schools is highly suggested to follow the direction of the transformation from "exam-oriented education" to "quality education", from the "curriculum reform” to "professionalism education", from "unification teaching" to "diversity development", and from "exhibitionism" to "characteristic development and personality development”.

In order to promote the transformation and development of the school, we need to go beyond. The development logic of decentralization and school choice is to start with the innovation of the easiest and most basic "school teaching system" to promote the comprehensive transformation and development of schools and institutional innovation. In the era of artificial intelligence, data-based, wearable intelligent devices and experience sharing teaching are changing the school teaching system. Firstly, it is necessary to reduce the government's direct intervention in the innovation of specific teaching affairs of schools, so as to provide space for creative teaching in the intelligent era, because the administrative-based development mode, to some extent, suppresses the enthusiasm and initiative of social participation in the reform and development of education, resulting in a single driving force for the development of education; secondly, we should reform the school classroom teaching system, implement intelligent curriculum programs and teaching plans for students and parents to choose, make clear the orientation of students' data-based and intelligent learning, actively cooperate with parents to promote teaching based on big data, and encourage teaching staff to use new teaching technologies of big data and cloud computing in teaching; thirdly, we should reform the knowledge teaching mode of traditional subjects and realize the optimization and integration of digital teaching resources. Students can use the teaching mode of grouping according to certain academic standards and abilities, rather than the traditional grading teaching according to age, so as to increase the flexibility of intelligent teaching system.

\section{Ways to achieve the education cooperation among family, school and society}

\subsection{Clarifying the responsibilities of the three parties}

Around children's growth, any unit or individual that can influence children's growth should not be bystanders or mechanical participants, and their respective influences are not limited to the respective fields of family, school and society, but will overflow and affect the educational functions of other fields, forming new and even unpredictable educational influences. To examine the subject of collaborative education in this way, it goes beyond the original single differentiation or mechanical synthesis mode of thinking, but an organic, holistic, ecological and symbiotic mode of thinking in the sense of ontology, which is called the new "subject relationship".

Families can play a role in correcting students' conduct, and the participation and cooperation of parents can help restrain students' bad conduct. Families should pay attention to the cultivation of children's moral quality and living habits, and the identity of parents should be more like the supervisor and direct example of students' behavior. As a theoretical and systematic educational institution, school plays a leading role in the establishment of the relationship among family, school, community and students themselves with good planning, thoughtful implementation, well-designed activities and targeted improvement, and then more and more families and teachers can benefit from the common interests of children.

\subsection{Establishing the cooperative education paradigm of equality and cooperation}

The equal cooperation between parties is an important basis and premise for building a harmonious relationship between family, school and society and maximizing the joint efforts. The so-called equal cooperation refers to the cooperation among families, schools and society on the basis of equality. Family, school and society are independent educational communities based on the common vision. The relationship between them determines the form and force of collaborative education, and whether its internal mechanism can be highlighted effectively. First of all, there is no order of educational influence in collaborative education. Family, school and society interact and influence each other in the process of children's education, but the influence is different with children's age-appropriate activities. The basic point of the three roles in equal cooperation is the same. They all focus on students, and their influence on students is syn- 
chronic. Secondly, the party status should be equal without subordination. Family, school and society are with equal and independent status, rather than the relationship of control and obedience. It is necessary to establish a stable education community on the basis of mutual respect, mutual trust and mutual dependence. In the process of equal consultation, dialogue and mutual support, it is necessary to make collaborative education go on a virtuous circle and work together. Thirdly, in order to achieve full participation, the school should strive to build a balanced cooperation system and cooperation projects, so as to enhance the willingness and confidence of all parents to participate in educational activities, such as providing educational services and support for all families, especially vulnerable families, through parent courses, training or lectures, so as to eliminate the worries and hidden worries of marginalized families (Hanwei Tang, 2019).

\subsection{Care-centered collaborative education}

Families, schools and society often neglect stimulating students to achieve self-fulfillment by paying attention to their potential psychological needs. However, internal traction can bring more success to students than external promotion. Therefore, it is proposed that care should be taken as the basic guidance in the process of collaborative education. Collaborative education requires families, schools and society to pay attention to students' emotional experience on the basis of trust and respect, so as to enhance students' self-identity. Parents should strengthen their children's awareness of the importance of school, homework and other activities, and create a school-like atmosphere in the family, while schools should mobilize the enthusiasm of all families to participate, respecting the students' personality growth, in order that students can develop a sense of identity and experience their own unique value in the caring situation.

The cooperative ecology of family, school and society should be harmonious, from which students can feel the resultant force of education from the three sources of influence. School encourages parents to actively participate in their children's learning activities and provide them with learning aids. Parents exhibit their support for teachers' work, and help their children strengthen their understanding of the importance of teachers, school assignments and activities, so as to transform them into students' positive attitude towards learning. As an important resource body outside the family and school, the society should try its best to cooperate with the collaborative education work by providing opportunities for students to show themselves by organizing recreational and voluntary activities, so that students can get recognition, encouragement and self-satisfaction from others because of their good quality in the activities.

In the actual process of collaborative education, schools should play a leading role, construct an effective two-way communication mechanism between school and family through various formal and informal channels, timely understand the parents' educational needs, ease the parents' resistance, and expand the content and channels of home school cooperation. Formal collaborative education channels include not only traditional ways such as parents' meeting, home visit and parents' open day, but also new ways such as home-school coeducation network platform based on mobile phone, Internet and other media. Informal channels include parents' participation in school activities, school decision-making and voluntary service. On the one hand, schools can develop experiential family education courses to help parents learn how to create a good family education environment, how to help children make choices and future plans, and improve the cooperation efficiency between home and school; on the other hand, parents can also be invited to participate in school activities as volunteers and parents' representatives to give advice and suggestions for school decision-making, or participate in the development, construction and implementation of curriculum, and provide voluntary services for school management.

\section{References}

Chaohui Chu. (2021). Collaborative Education Strategies among Family, School and Society. People1's Education, 33 , 8.

Demetriou Loukia1 and Kalouri Ourania. (2019). Parental Effectiveness and School Counselling in Elementary Education. Speech at International Academic Conference on Teaching, Learning and Education, Oct. 30.

Hanwei Tang. (2019). Enlightenment of overlapping influence threshold theory on collaborative education of primary and secondary schools in China. Journal of Shandong Normal University, 4, 103.

Jeffrey Shulman. (2010). The Parent as (Mere) Educational Trustee: Whose Education Is It, Anyway? Neb. L. Rev., 89, 290.

The Chinese Government. (2021). The Fourteenth Five-year Plan for National Economic and Social Development of the People's Republic of China and the Outline of Long-term Goals for 2035. http://www.gov.cn/zhengce/2020-11/ 03/content_5556991.html.

The National People's Congress of P.R.C. (2021). The Family Education Law of the People's Republic of China (draft). http://www.npc.gov.cn/npc/jtjyfca/jtjyfca.shtml. 